\title{
Investigation of genital hygiene behavior: An example of slum area
}

\section{Genital hijyen davranışlarının belirlenmesi: Gecekondu bölgesi örneği}

\author{
Ebru Gözüyeşil ${ }^{*}$ (I) \\ ${ }^{1}$ Cukurova University, Adana, Turkey \\ * Corresponding author: Ebru Gözüyeşil E-mail: ebrugozuyesil@hotmail.com ORCID: 0000-0002-9193-2182 \\ Received: 16 December 2019 Accepted: 8 March 2020
}

\begin{abstract}
Aim: This study was conducted to evaluate the genital hygiene behaviors of women living in a slum area.

Method: This descriptive research, which was conducted with women living in low socioeconomic level in Akıncılar and Suluca region of Adana. The population of the study was composed of approximately 420 women who living in Akıncılar and Suluca region. The sample was calculated by simple random sampling method and 146 women were included in the study. Data was collected using a Personal Information Form and Genital Hygiene Behaviors Inventory. The obtained data was analyzed using Mann-Whitney $U$, Kruskal-Wallis and Post-hoc test statistics.

Results: It was determined that the average age of the women was $31.25 \pm 10.42,48.6 \%$ of them are illiterate, all of them married, not working and income perceptions are less than the income. It was determined that total median score of women from Genital Hygiene Behaviors Inventory are 46. It was found that the difference between Genital Hygiene Behaviors Inventory median scores of women according to educational status, educational status of spouses, perceptions of nutritional status, smoking status and frequency of changing daily pad were significant $(p<0.05)$.
\end{abstract}

Conclusions: In this research, it was determined that Genital Hygiene Behaviors of women living in a slum area are insufficient.

Keywords: genital hygiene, women health, socioeconomic status

() 2020 by the authors; licensee MEDITAGEM Ltd., Turkey. This article is an open access article distributed under the terms and conditions of the Creative Commons Attribution License (http://creativecommons.org/licenses/by/4.0/). 


\section{ÖZ}

Amaç: Bu araştırma gecekondu bölgesinde yaşayan kadınların genital hijyen davranışlarının belirlenmesi amacıyla yapılmıştır.

Yöntem: Tanımlayıcı tipte bu araştırma, Adana'nın Akıncılar ve Suluca bölgesinde yaşayan sosyoekonomik düzeyi düşük kadınlar ile yürütülmüştür. Araştırmanın evrenini Akıncılar ve Suluca bölgesinde yaşayan yaklaşık 420 kadın oluşturmuştur. Örneklemi ise basit rastgele örneklem yöntemi ile hesaplanmış ve 146 kadın araştırmaya dâhil edilmiştir. Veriler; Kişisel Bilgi Formu ve Genital Hijyen Davranışları Envanteri kullanılarak toplanmıştır. Verilerin değerlendirilmesinde Mann Whitney U, Kruskal Wallis ve Post-hoc test istatistiği kullanılmıştır.

Bulgular: Kadınların yaş ortalamasının 31,25 10,42 olduğu, \%48,6'sının okuryazar olmadığı, tamamının evli olduğu, çalışmadığı ve gelir durumu algılarının gelirlerinin giderlerinden az olduğu belirlenmiştir. Kadınların Genital Hijyen Davranışları Envanteri toplam puan ortanca değeri 46 olarak saptanmıştır. Kadınların eğitim durumları, eşlerinin eğitim durumları, beslenme durumu algıları, sigara içme durumları ve günlük ped değiştirme sıklığı değişkenlerine göre Genital Hijyen Davranışları Envanteri toplam ortanca değerleri arasında istatistiksel olarak anlamlı farklılık saptanmıştır $(p<0,05)$.

Sonuç: Bu araştırmada gecekondu bölgesinde yaşayan kadınların genital hijyen davranışlarının yetersiz olduğu saptanmıştır.

Anahtar kelimeler: genital hijyen, kadın sağlığı, sosyoekonomik statü

\section{INTRODUCTION}

Genital infections are one of the health problems from which women have frequently suffered. Genital infections result from many reasons, among which the anatomical structure ranks first. Although the normal vaginal flora in the female reproductive system provides a natural protection mechanism, the risk of the genital infection does increase since the urethra, vagina and anus are juxtaposed [1,2]. In addition, many factors including more than one partner, inappropriate menstrual, toilet and post-coital hygiene habits, the wear of narrow and synthetic clothing, malnutrition, systemic diseases (diabetes), more than one birth, miscarriage and curettage, long and intense stress, long-term antibiotic and steroid use, vaginal douching, tampon use, poor environmental conditions caused by low socio-economic status, and lack of education contribute to the development of genital infections $[1,3,4]$. Ensuring genital hygiene is one of the most critical elements in the protection and maintenance of women's health and reproductive health.

Susceptibility to the genital infection can increase when great attention is not paid to genital hygiene. Serious complications occur when the infection is not treated [5]. These complications are low birth weight infants, fetal abortion and fetal death, congenital infections in the newborn, ectopic pregnancy, sepsis, cervical cancer, infertility and chronic pelvic pain $[1,6]$. Moreover, psychological and sexual problems, social isolation, fatigue and deterioration in the quality of life can be observed in women [7].

Gypsies in Turkey go on with their lives especially in rural areas [8]. It is known that half a million to 5 million Gypsy citizens reside in Turkey [9]. From the past to the present, the Gypsies have maintained their life along with many problems such as social exclusion, poverty, unemployment, housing, and the inability to access and benefit from basic rights and services [8].

Gypsies in Turkey, in general, have been living in the slum areas that are lack of sanitary conditions [10]. Early marriages, adolescent pregnancies, drug addiction, infant and child deaths, difficulties of nomadic life, insufficient hygiene conditions, malnutrition, unprotected sexual intercourse, unwillingness to use condoms, high incidence of infectious diseases, limited use of healthcare resources, lack of communication with health professionals and many negative behaviors affecting health are more common among Gypsies [11-13].

There are many studies examining genital hygiene behaviors in Turkey [5,14-20]. However, a limited number of studies investigating genital hygiene behaviors have been found especially in disadvantaged groups [2,4,21-23]. Midwives and nurses play very important roles in the protection, maintenance, and improvement of women's health. Therefore, identifying disadvantaged groups with especially low socioeconomic status and high environmental risk factors, assessing whether women in this 
group are aware of the risk factors for the prevention of genital infections and determining whether they need education are the first actions to be taken in terms of maintaining preventive health services. Thus, this study was aimed to evaluate the genital hygiene practices of women living in slum areas.

\section{MATERIAL AND METHODS}

Type of research: This study was conducted in a descriptive manner to evaluate the genital hygiene behaviors of women living in a slum area.

Research site: This study was carried out with women living in Akıncilar and Suluca that are densely populated by Gypsies in the district Yüreğir of Adana.

Population and Sample of Study: When the population of the study is considered to consists of approximately 420 women living in Akıncılar and Suluca, a minimum of $n=146$ women able to be included in the study was calculated by simple random sampling method whose population is known and 146 women were included in the study.

Inclusion Criteria: All women, who accepted to participate in the research and were Gypsies and married, were included in the study. Women with communication difficulties and mental disabilities were excluded from the study.

Data Collection Forms and Tools: The study data were gathered using a Personal Information Form and Genital Hygiene Behavior Inventory (GHBI).

1- Personal Information Form: This is a 22-item data collection form that is prepared by the researcher in accordance with the literature review and evaluates sociodemographic, obstetric and gynecological characteristics of women $[2,5,7,21]$.

2- Genital Hygiene Behavior Inventory: GHBI was developed by Ege and Eryılmaz in 2005 [24]. The inventory consists of 27 questions regarding general hygiene, menstrual hygiene, toilet hygiene, and sexual hygiene. GHBI is a one-dimensional measurement tool specific to Turkish culture. The inventory is suitable for all sexually active women found in a group of ages from 15 to 49 . Questions in GHBI were answered as "1-never", "2-sometimes", "3-often", "4-always. The negative items (17, 26 and 27) of the inventory were coded in reverse order to ensure compliance with the measurement. The lowest score from the inventory was 27 and the highest score was 108. The total score from the inventory gives the score of genital hygiene behavior. As the score increases, it is understood that genital hygiene behaviors reach the desired level. Cronbach's alpha coefficient of the scale was 0.86 [24].

Data Collection: The data were gathered by the researcher between May 10 to September 10, 2019. The researcher went to the relevant areas once a week on average to collect data. Data were collected through the face-to-face interview method in a suitable environment by protecting the privacy of women who meet the sampling criteria. Data collection was completed within approximately 5-10 minutes.

Data Evaluation: Coding and evaluation of the data were carried out in a computer environment. SPSS (Statistical Package of Social Science) 24.0 software was used to analyze the data. Frequency tables and descriptive statistics were employed for the analysis of the data. Kolmogorov-Smirnov test was used to test whether the data are normally distributed, and it was found that they did not exhibit a normal distribution. Mann-Whitney $U$ test was used to compare two independent groups with measurement values while Kruskal-Wallis test was utilized to compare three or more independent groups with measurement values. The post-hoc test was used for further analysis. Results were evaluated at a 95\% confidence interval. $p<0.05$ was considered statistically significant.

Ethical Declarations: The study was conducted in accordance with the principles of the Declaration of Helsinki. The Ethics Committee Decision (Date: 06.05.2019, Permission no: 2019/7/1) permission were obtained from Scientific Research and Publication Ethics Committee of Osmaniye Korkut Ata University. In addition, the objective of the study was explained to the participants and written approval was obtained from them via an informed consent form.

\section{RESULTS}

The mean age of the women was $31.25 \pm 10.42$ (min: 20 max: 55$) .48 .6 \%$ of them were illiterate. All were married and were not working. Their incomes were lower than their expenditure. $53.4 \%$ of them had 3 or more children. $44.5 \%$ of them did not use any contraceptive methods. $46.6 \%$ of them had no normal vaginal discharge. $87.7 \%$ of them had vaginal douching after sexual intercourse. $76.1 \%$ of them changed pad four times or less a day at periods when menstruation was intensified. Table $\mathbf{1}$ presents other findings related to the descriptive, obstetric and gynecological characteristics of women. 
Table 1. Distribution of women according to descriptive, obstetric and gynecological characteristics

\begin{tabular}{|c|c|c|}
\hline Descriptive characteristics & $\mathrm{X} \pm \mathrm{SD}$ & Min-Max \\
\hline Age average & $31.25 \pm 8.78$ & $20-55$ \\
\hline Average number of pregnancies & $3.56 \pm 2.2$ & $0-18$ \\
\hline Average number of children & $2.72 \pm 1.3$ & $0-9$ \\
\hline Average number of curettages & $0.74 \pm 1.0$ & $0-7$ \\
\hline Age average of menarche & $12.65 \pm 1.2$ & $10-17$ \\
\hline \multirow[t]{2}{*}{ Average of smoking per day } & $13.95 \pm 9.3$ & $2-40$ \\
\hline & $\mathbf{n}$ & $\%$ \\
\hline \multicolumn{3}{|l|}{ Educational status } \\
\hline Illiterate & 71 & 48.6 \\
\hline Literate & 6 & 4.1 \\
\hline Primary school & 59 & 40.1 \\
\hline Secondary school & 10 & 6.8 \\
\hline High school & 0 & 0.0 \\
\hline \multicolumn{3}{|l|}{\begin{tabular}{|l} 
Educational status of spouse \\
\end{tabular}} \\
\hline Illiterate & 39 & 26.7 \\
\hline Literate & 9 & 6.2 \\
\hline Primary school & 76 & 52.1 \\
\hline Secondary school & 14 & 9.6 \\
\hline High school & 8 & 5.5 \\
\hline \multicolumn{3}{|l|}{\begin{tabular}{|l} 
Age \\
\end{tabular}} \\
\hline $20-29$ & 63 & 43.2 \\
\hline $30-39$ & 53 & 36.3 \\
\hline $40-49$ & 24 & 16.4 \\
\hline $50-59$ & 6 & 4.1 \\
\hline \multicolumn{2}{|l|}{ Working condition } & 100 \\
\hline \multicolumn{3}{|l|}{ Income perception } \\
\hline \multicolumn{3}{|l|}{\begin{tabular}{|l|} 
Nutritional status perception \\
\end{tabular}} \\
\hline Good & 26 & 17.8 \\
\hline Moderate & 47 & 32.2 \\
\hline Poor & 73 & 50.0 \\
\hline \multicolumn{3}{|l|}{ Number of pregnancies } \\
\hline $0-2$ & 46 & 31.5 \\
\hline 3 and over & 100 & 68.5 \\
\hline \multicolumn{3}{|l|}{ Number of living children } \\
\hline $0-2$ & 68 & 46.6 \\
\hline 3 and over & 78 & 53.4 \\
\hline \multicolumn{3}{|l|}{ Smoking status } \\
\hline Yes & 45 & 30.8 \\
\hline No & 101 & 69.2 \\
\hline \multicolumn{3}{|l|}{ Contraception Methods } \\
\hline OK & 10 & 6.8 \\
\hline RIA & 37 & 25.3 \\
\hline Condom & 3 & 2.1 \\
\hline Withdrawal & 14 & 9.6 \\
\hline Injection & 9 & 6.2 \\
\hline Tube-ligation & 7 & 4.8 \\
\hline No contraception & 65 & 44.5 \\
\hline \multicolumn{3}{|l|}{ Menopause } \\
\hline Yes & 5 & 3.4 \\
\hline No & 141 & 96.6 \\
\hline \multicolumn{3}{|l|}{ Discharge } \\
\hline Normal, odorless, itchless & 78 & 53.4 \\
\hline Anormal (malodorous/plentiful/itchy,cheesy) & 68 & 46.6 \\
\hline \multicolumn{3}{|l|}{ Vaginal douching } \\
\hline Yes & 128 & 87.7 \\
\hline No & 18 & 12.3 \\
\hline \multicolumn{3}{|l|}{\begin{tabular}{|l|} 
Presence of gynecological disease \\
\end{tabular}} \\
\hline Yes & 14 & 9.6 \\
\hline No & 132 & 90.4 \\
\hline \multicolumn{3}{|l|}{ Frequency of changing pad (piece per day) } \\
\hline $0-4$ & 111 & 76.1 \\
\hline 5 and over & 35 & 23.9 \\
\hline
\end{tabular}

Table 2. Mean of Genital Hygiene Behavior Scale (GHBS)

\begin{tabular}{|c|c|c|}
\hline Scale & Score mean of GHBI & Median (Min-Max) \\
\hline \multicolumn{3}{|r|}{$n=146$} \\
\hline Total score of GHB & $46.17 \pm 4.27$ & $46(36-58)$ \\
\hline
\end{tabular}

The total median GHBI value of women was found as 46 (min: 36 - max: 58), as shown in Table 2. Cronbach's alpha value of the scale was calculated as 0.658 . When the findings comparing the $\mathrm{GHBI}$ scores according to the descriptive, obstetric and gynecological characteristics of women were examined, a statistically significant relationship was found between women's educational status and total median values of $\mathrm{GHBI}(\mathrm{p}<0.05)$. Further analysis revealed that the difference results from the illiterate group ( $p<0.05$; Table 3 ). There had been a statistically significant relationship between the education status of women's spouses and the total median values of $\mathrm{GHBI}(\mathrm{p}<0.05)$. Further analysis showed that the difference is due to the group who finished high school education ( $p<0.05$; Table 3 ). There existed a statistically significant relationship between the nutritional status of women's spouses and the total median values of GHBI $[p<0.05)$. Further analysis demonstrated that the difference was caused by the group with a poor perception of nutritional status $(p<0.05$; Table 3$)$. A statistically significant relationship was found between the total median values of $\mathrm{GHBl}$ according to the smoking status and daily frequency of pad change of women ( $p<0.05$; Table 3 ).

\section{DISCUSSION}

This study was conducted with women living in Akıncılar and Suluca rural areas of Adana. The most important feature of these areas is that the socio-economic level is low and gypsies mostly live. It has been found that $48.6 \%$ of the gypsy women living in the study area were illiterate, all of them were not working, all of them had poor income perceptions and $50 \%$ of them had poor perceptions of nutritional status. Eskiocak et al. (2017) carried out a study on the health of the gypsies living in Edirne. They reported that being born as a gypsy constitutes a disadvantage in terms of healthily holding on to life and gypsies live a disadvantaged life in the fields of housing, nutrition, education, employment and social security [25]. In addition, it has been indicated that the research results carried out in Turkey and worldwide are similar to the scene in Edirne. These studies revealed that the unemployment rate is higher in gypsies, and gypsies are poorer than non-gypsies [25-27]. Kolukırık (2006) also reported that the biggest problems perceived by the gypsies were unemployment, poverty and lack of education [28]. Similarly, a study by Tanriverdi (2014) reported that poverty and unemployment 
Table 3. Comparison of GHBI scores by the descriptive, obstetric and gynecological characteristics of women

\begin{tabular}{|c|c|c|}
\hline & $\begin{array}{c}\text { Total median } \\
\text { score of GHBI } \\
\text { (min-max) }\end{array}$ & $\begin{array}{c}\text { Test } \\
\text { statistics }\end{array}$ \\
\hline \multicolumn{3}{|l|}{ Educational status } \\
\hline Illiterate & $44(36-57)$ & \\
\hline Literate & $47.5(42-51)$ & \\
\hline Primary school & $47(39-56)$ & $X^{2}=17.065$ \\
\hline Secondary school & $49.5(47-58)$ & $p=0.002$ \\
\hline \multicolumn{3}{|l|}{ Educational status of spouse } \\
\hline Illiterate & $45(36-58)$ & \\
\hline Literate & $45(41-51)$ & \\
\hline Primary school & $46(38-57)$ & \\
\hline Secondary school & $48(41-51)$ & $X^{2}=10.639$ \\
\hline High school & $49.5(46-56)$ & $p=0.031$ \\
\hline \multicolumn{3}{|l|}{ Age } \\
\hline $20-29$ & $47(36-58)$ & \\
\hline $30-39$ & $46(39-55)$ & \\
\hline $40-49$ & $47(39-57)$ & $X^{2}=0.787$ \\
\hline $50-59$ & $41(38-46)$ & $p=0.675$ \\
\hline \multicolumn{3}{|l|}{ Nutritional status perception } \\
\hline Good & $49(44-54)$ & \\
\hline Moderate & $46(36-58)$ & $X^{2}=15.779$ \\
\hline Poor & $44(38-57)$ & $p=0.000$ \\
\hline \multicolumn{3}{|l|}{ Number of pregnancies } \\
\hline $0-2$ & $46(36-58)$ & $Z=-0.154$ \\
\hline 3 and over & $46(38-57)$ & $p=0.877$ \\
\hline \multicolumn{3}{|l|}{ Number of living children } \\
\hline $0-2$ & $46(36-58)$ & $Z=-0.380$ \\
\hline 3 and over & $46(39-56)$ & $p=0.704$ \\
\hline \multicolumn{3}{|l|}{ Smoking status } \\
\hline Yes & $44(36-57)$ & $Z=-2.278$ \\
\hline No & $47(39-58)$ & $p=0.023$ \\
\hline \multicolumn{3}{|l|}{ Contraception Methods } \\
\hline OK & $45.5(42-50)$ & \\
\hline RIA & $45(39-57)$ & \\
\hline Condom & $47(44-48)$ & \\
\hline Withdrawal & $47(39-55)$ & \\
\hline Injection & $48(39-51)$ & \\
\hline Tube-ligation & $50(40-50)$ & $X^{2}=2.760$ \\
\hline No contraception & $46(36-58)$ & $\mathrm{p}=0.838$ \\
\hline \multicolumn{3}{|l|}{ Menopause } \\
\hline Yes & $40(38-56)$ & $Z=-1.926$ \\
\hline No & $46(36-58)$ & $p=0.054$ \\
\hline \multicolumn{3}{|l|}{ Discharge } \\
\hline Normal, odorless, itchless & $46(38-58)$ & $Z=-0.659$ \\
\hline Anormal (malodorous/plentiful/itchy, cheesy) & $45(33-54)$ & $p=0.510$ \\
\hline \multicolumn{3}{|l|}{ Vaginal douching } \\
\hline Yes & $46(36-58)$ & $Z=-0.904$ \\
\hline No & $47(41-53)$ & $p=0.366$ \\
\hline \multicolumn{3}{|l|}{ Presence of gynecological disease } \\
\hline Yes & $44.5(39-56)$ & $Z=-0.213$ \\
\hline No & $46(36-58)$ & $p=0.831$ \\
\hline \multicolumn{3}{|l|}{ Frequency of changing pad (piece per day) } \\
\hline $0-4$ & $45(36-57)$ & $Z=-\mathbf{3 . 8 8 8}$ \\
\hline 5 and over & $48(41-58)$ & $p=0.000$ \\
\hline
\end{tabular}

were the most commonly experienced problems [11]. Consistent with the literature, the disadvantages from which the gypsies suffered are overlapped with our research findings.

We found that $76.1 \%$ of gypsy women changed pad four times or less a day at intensive periods of menstruation. The low frequency of pad changing shows that women have insufficient knowledge about the maintenance of genital hygiene. In a study on the living conditions and genital hygiene practices of seasonal agricultural workers, Yağmur and Ergin (2017) found that only $12.2 \%$ of women changed pad 4 or more times per day during menstruation [4]. Karatay and Özvarış (2006) investigated the genital hygiene practices of women living in the slum area and found that 93.3\% of women changed pad 4 or less per day [2]. Daşıkan et al. (2015) reported that $50.4 \%$ of women changed their pads or tampons 1-2 times per day [5]. Other studies also reported that the frequency of changing pad during menstruation was insufficient [14,23,29-31]. We established that $87.7 \%$ of the gypsy women applied vaginal douching after sexual intercourse. Vaginal douching, which destroys the normal flora of the vagina, poses a high risk for many female genital diseases and thus predispose women to vaginal infections, is often preferred by women in many countries of the world, especially in Muslim countries [18,3234]. Pete et al. (2019) reported that women in Cameron used vaginal douching, which has been a cultural practice, and that $53.8 \%$ of them have inherited this tradition from their family [33]. Another study in Africa reported that they performed mostly vaginal douching since black women believed that the vagina contained germs [32]. Sunay et al. (2011) reported that women performing vaginal douching had a 3.9-fold higher risk of abnormal vaginal discharge than those who did not [34]. Cangöl and Tokuç (2013) reported that almost all of the women clean their vagina after sexual intercourse [15]. Other studies also indicated that vaginal douching was performed by women within the range of 51.4 to $87 \%[2,5,14,18]$. In line with these results, it is possible to say that some incorrect practices of genital hygiene have still continued to be done.

One of the important indicators of poor genital hygiene behavior is abnormal vaginal discharge. Several studies revealed that insufficient genital hygiene behaviors are one of the most important reasons for vaginal infection [20,31]. We found that $46.6 \%$ of the gypsy women had abnormal vaginal discharge (malodorous/abundant/itchy-cheesy). Yağmur and Ergin (2017) reported that approximately onefifth of women working seasonally in agricultural activities had previously faced vaginal infection [4]. Karatay and Özvarış (2006) stated that $72.8 \%$ of the women living in the slum area experienced an abnormal discharge problem in 
the past and $28.7 \%$ of them have still suffered from abnormal discharge problems [2]. Arslan Özkan and Kulakaç (2011) reported that $30.1 \%$ of women prisoners faced abnormal discharge problems [22]. In addition, Yılmaz and Kahraman (2019) found the rate of incidence of abnormal vaginal discharge as $62.7 \%$ [35]. Srivastava (2010) reported that $72.6 \%$ of women living in the rural areas of India developed one or more genital infections and that more than half of the participating women had poor menstrual hygiene practices [36]. All these results show us that women living in regions with especially low socio-economic level need more gynecological help and counseling.

In this study, the total median value of GHBI of women was found as 46 (min: 36 - max: 58) (Table 2). When the lowest score to be obtained from the scale is 27 and the highest score is 108 , it can say that the total median values of $\mathrm{GHBI}$ of gypsy women are less than expected. This is a possible outcome in especially gypsies who are regarded as disadvantaged groups. When the relevant studies are examined, llgaz et al. (2015) found that the total score of $\mathrm{GHBI}$ was 72.1, and genital hygiene behaviors in women living in regions with low socioeconomic level were 5.5 times more negative than those living in regions with high socioeconomic level [21]. Arslan Özkan and Kulakaç (2011) found the mean GHBI of female prisoners to be 86.6 [22]. Karatay and Özvarış (2006) also reported that rural life entails a risk for genital hygiene behaviors. A study on Indian women revealed that genital infections were more common in rural areas than in urban those [37]. Research results show that rural life poses a risk for genital hygiene.

A statistically significant relationship was found between the total median values of GHBI of women according to their educational background ( $\mathrm{p}<0.05)$. Further analysis revealed that the difference was due to the illiterate group ( $p<0.05$; Table 3). In other words, a low level of education leads to a decrease in the total score of GHBI. The studies have already reported that the education level of gypsies is generally low $[11,25,28]$. Tanriverdi et al. (2014) found that gypsies suffered badly from negativities such as unhealthy nutrition, adverse environmental conditions, inadequate use of secondary and tertiary health care services, poor hygiene and insufficiency in healthy lifestyle behaviors [11]. Koştu and Beydağ (2009) stated that the genital hygiene behaviors of women in high school and higher education level were better [14]. Daşıkan et al. (2015) found that women with the educational level of primary education and below experienced more complaints of genital discharge [5]. Yağmur and Ergin found vaginal infection to be mostly seen in the illiterate group [4]. A statistically significant relationship was found between the total median values of $\mathrm{GHBI}$ according to women's perceptions of nutritional status ( $p<0.05)$. Further analysis showed the difference resulted from the group with a poor perception of nutritional status ( $p<0.05$; Table 3 ). Women with poor nutritional status perception had lower total median values of $\mathrm{GHBI}$. Tanrıverdi et al. (2014) reported that gypsies could not eat properly due to economic deficiency in general [11]. Half of the women participating in our study were found to have poor perceptions of nutrition. We can say that these emergent outcomes are caused by low socioeconomic level.

Tanrıverdi et al. (2014) reported that smoking was widespread among gypsy women [11]. A statistically significant relationship was found between the total median values of $\mathrm{GHBI}$ according to the smoking status of women ( $p$ $<0.05$; Table 3). Smoking women had lower total median values of GHBI. We can say that the general health outcomes of women who do not exhibit healthy lifestyle behaviors may be poor and their genital hygiene behaviors may also be more negative. There was a statistically significant relationship between the total median values of $\mathrm{GHBI}$ of women according to the frequency of daily pad change during the menstruation period ( $p<0.05$; Table 3 ). Women changing pad 5 or more times per day had a higher total median value of GHBI. Koştu and Beydağ (2009) found that women with more frequent pad change daily had a higher mean score of GHBI [14]. Yağmur and Ergin (2017) found that vaginal infections were highly seen in those with the insufficient frequency of daily pad changing [4]. Kahyaoğulu Süt (2016) reported that changing pad less than 4 during the intensive days of menstruation increases the incidence of a genital infection [17]. Our results show that women frequently changing pads during menstruation care more about genital hygiene behaviors.

\section{CONCLUSIONS AND RECOMMENDATIONS}

The results of this research suggest that women living in slum areas of the province Adana are poor genital hygiene behaviors and women's genital hygiene behavior is affected by educational level, nutritional status, smoking status, and frequency of changing pad daily. It has been found that women have educational requirements of genital hygiene behaviors.

In line with these results, the researcher prepared a training program involving the protection of genital infections and the proper application of genital hygiene practices for women living in the study area. 


\section{DECLARATION OF CONFLICT OF INTEREST}

The author received no financial support for the research and/or authorship of this article. There is no conflict of interest.

\section{REFERENCES}

1. Hotun Şahin N, Bilgiç D. Üreme sistemi enfeksiyonları. Kızılkaya Beji N. Hemşire ve Ebelere Yönelik Kadın Sağlığı ve Hastalıkları, 1. Ed., İstanbul, Nobel Tıp Kitabevleri, 2015.

2. Karatay G, Özvarış ŞB. Bir sağlık merkezi bölgesindeki gecekondularda yaşayan kadınların genital hijyene ilişkin uygulamalarının değerlendirilmesi. C.Ü. Hemşirelik Yüksekokulu Dergisi 2006; 10(1): 7-14.

3. Can Gürkan Ö. Üreme sistemi enfeksiyonları ve cinsel yolla bulaşan enfeksiyonlar. In: Arslan Özkan $\mathrm{H}$. Hemşirelik ve Ebelik İçin Kadın Sağlığı ve Hastalıkları, 1. Ed., Ankara, Akademisyen Kitabevi, 2019.

4. Yağmur E, Ergin i̇o. Mevsimlik tarım işçisi kadınların yaşam koşulları ve genital hijyen uygulamaları. Uluslararası Sosyal Araştırmalar Dergisi 2017; 10(51): 61420.

5. Daşıkan Z, Kılıç B, Baytok C, Kocairi H, Kuzu S. Genital akıntı şikâyetiyle polikliniğe başvuran kadınların genital hijyen uygulamaları. GÜSBD 2015; 4(1): 113-24.

6. Taşkın L. Doğum ve Kadın Sağlığı Hemşireliği: Üreme Sistemi Enfeksiyonları ve Cinsel Yolla Bulaşan Hastalıklar, XIII. Baskı, Ankara, Akademisyen Tıp Kitabevi, 2016.

7. Ejder Apay S, et al. Yedi farklı ildeki kadınların genital hijyen davranışlarının belirlenmesi: çok merkezli kesitsel bir çalışma, Anadolu Hemşirelik ve Sağlık Bilimleri Dergisi 2014; 17(4): 245-52.

8. Çetin BI. Kimlikleriyle romanlar: Türkiye'deki roman vatandaşlara yönelik sosyal içerme Ulusal Strateji Belgesi ve Birinci Aşama Eylem Planı́nın değerlendirilmesi. Yönetim ve Ekonomi Araştırmaları Dergisi 2017; 15(1): 85-112.

9. Siroma 2016, Türkiye' de Roman yurttaşların sorunları ve çözüme ilişkin çalışmalar; Romanların yoğun olarak yaşadığı alanlarda sosyal içermenin desteklenmesi operasyonu için Teknik Destek Projesi (SiROMA), Ankara; 2016.

10. Arayıcı A. Avrupa'nın Vatansızları: Çingeneler. Birinci Basım. İstanbul: Kalkedon yayınları; 2008: 40-5.
11. Tanrıverdi G, et al. Çanakkalede'de yaşayan Romanların Purnell'in kültürel yeterlilik modeli ile değerlendirilmesi. Anadolu Hemşirelik ve Sağlık Bilimleri Dergisi 2012; 15(4): 244-53.

12. Campayo JG, Alda M. Illness behaviors and cultural characteristics of the gypsy population in spain. Actas Espanolas Psiquiatria 2007; 35(1): 59-66.

13. Dion X. Gypsies and travellers: cultural influences on health. Community Practitioners 2008; 81(6): 31-4.

14. Koştu N, Beydağ K.D. Jinekoloji polikliniğine başvuran kadınların genital hijyen davranışları. Anadolu Hemşirelik ve Sağlık Bilimleri Dergisi 2009; 12(1): 66-71.

15. Cangöl E, Tokuç B. Jinokoloji polikliniğine başvuran kadınlarda genital enfeksiyon sıklığı ve genital hijyen davranışları. F.N. Hemşirelik Dergisi 2013; 21(2): 85-91.

16. Ege E, Eryılmaz G. Kadınlara verilen planlı eğitimin genital hijyen davranışlarına etkisi. Anadolu Hemşirelik ve Sağlık Bilimleri Dergisi 2006; 9(3): 8-16.

17. Kahyaoğlu Süt H. 18-49 yaş arası kadınlarda genital hijyen davranışları ile genital enfeksiyon arasındaki ilişkinin incelenmesi. DÜ Sağlık Bilimleri Enstitü Dergisi 2016; 6(1): 8-13.

18. Hacıalioğlu N, Nazik E, Kılıç MA. Descriptive study of douching practices in Turkish women. International Journal of Nursing Practice 2009; 15: 57-64.

19. Ege E, Timur S, Zincir H, Sunar Reeder B. Women's douching practices and related attitudes in Eastern Turkey. J. Obstet. Gynaecol 2007; 33(3): 353-9.

20. Kısa S, Taskın L. Behavioral risk factors that predispose women to vaginal infections in Turkey. Pak J Med Sci 2010; 26: 800-4.

21. Ilgaz A, Sevinç Ö, Utku Uzun S. İki farklı aile sağlığı merkezine kayıtlı doğurgan çağdaki evli kadınların genital hijyen davranışları. TAF Prev Med Bull 2015; 14(2): 153-60.

22. Arslan Özkan İ, Kulakaç Ö. Kadın mahkumlarda genital hijyen davranışları. Anadolu Hemşirelik ve Sağlık Bilimleri Dergisi 2011; 14(2): 31-8.

23. Yaşar BN, Terzioğlu F, Koç G. Knowledge and practices of genital hygiene: visual-disabled women sample. DEUHFED 2017; 10 (3): 123-30. 
24. Ege E, Eryılmaz G. Genital hijyen davranışları envanterinin (GHDE) geliştirilmesi. Anadolu Hemşirelik ve Sağlık Bilimleri Dergisi 2005; 8(3): 67-75.

25. Eskiocak M, Akbaşak D. Edirne'de Romanların sağlığı: Sağlığın sosyal belirleyicileri ve sağlık durumlarına yönelik bulgular. Turk J Public Health 2017; 15(2): 136-49.

26. Colombini M, Rechel B, Mayhew SH. Access of Roma to sexual and reproductive health services: Qualitative findings from Albania, Bulgaria and Macedonia. Glob Public Health. 2012; 7(5): 522-34.

27. UNDP. The health situation of Roma communities: Analysis of the data from the UNDP/World Bank/EC Regional Roma Survey 2011. Roma Inclusion Working Papers. 2012.

28. Kolukırık S. Sosyolojik perspektiften Türkiye Çingeneleri: İzmir Çingeneleri üzerine bir araştırma. Uluslararası İnsan Bilimleri Dergisi 2006; 3(1): 1-24.

29. Yurttaş A, Gültekin Ü, Ejder Apay S. İdrar yolu enfeksiyonu geçiren 15-49 yaş arası kadınların perine bakımı uygulamalarının incelenmesi. ACU Sağlık Bil Derg 2018; 9(3): 297-301.

30. Ocaktan ME, Baran E, Akdur R. Evaluation of habitual behavior related to genital hygiene in women living in a health care center area. Saudi Med J 2010; 31(11): 12516.

31. Dalbudak S, Bilgili N. GATA kadın hastalıkları ve doğum polikliniğine başvuran kadınların genital hijyen davranışları ve bu davranışların vajinal enfeksiyona etkisi. Gülhane Tıp Derg 2013; 55: 281-7.
32. Funkhouser E, Pulley L, Lueschen G, Costello C, Hook E, Vermund $\mathrm{SH}$. Douching beliefs and practices among black and white women. J Womens Health Gend Based Med 2002; 11: 29-37.

33. Pete PMN, Biguioh RM, Izacar AGB, Adogaye SBB, Nguemo $C$. Genital hygiene behaviors and practices: $A$ cross-sectional descriptive study among antenatal care attendees. Journal of Public Health in Africa 2019; 10(1): 6-10.

34. Sunay D, Kaya E, Ergün Y. Kadınların vajinal duş davranışları ve vajinal duşun vajinal akıntı ve demografik faktörlerle ilişkisi. J Turk Soc Obstet Gynecol 2011; 8(4): 264-71.

35. Yılmaz S, Kahraman S. Şanlıurfa'da adölesan dönemde kızların genital bölge ve hijyeni ile ilgili bilgi, uygulamaları ve etkileyen faktörler. Uluslararası İnsan Bilimleri Dergisi 2019; 16(3): 823-32.

36. Srivastava L. Reproductive tract Infections among women of rural community in Mewat, India. Journal of Health Management 2010; 12(4): 519-38.

37. Arora BB. Prevalence of trichomoniasis, vaginal candidiasis, genital herpes, chlamydiasis, and actinomycosis among urban and rural women of Haryana, India. Journal of Sexually Transmitted Diseases 2014: 1-5. 